Yanko Hristov (Blagoevgrad)

(iD) https://orcid.org/0000-0001-7882-9749

Valentin Kitanov (Blagoevgrad)

(iD) https://orcid.org/0000-0002-8361-5830

\title{
The Spoils of War "Divided into Three Parts": A Comparison between Two Accounts in Skylitzes’ SyNOPSIS historiarum AND Kritoboulos' History OF MEHMED THE CONQUEROR
}

\section{Introduction}

C or those who lived in the medieval epoch as well as for modern day people, 1 there is no serious doubt of the statement that every historical moment is unique with its own characteristics. Nevertheless, when we focus on the medieval Balkans and Asia Minor, it appears as if there are a significant number of instances that reveal remarkable similarities. A series of identical moments and processes have appeared several times in the history of Byzantium as well as in the history of Balkan societies as whole. The present short remarks are focused on two descriptions of the well-known historical events. The first one - the seize of Longos fortress and the pillage of the Pelagonian plain by the army of Emperor Basil II in 1017 - described by John Skylitzes in Synopsis historiarum; while the record of the second one - the Ottoman conquest of Mytilene (island of Lesbos) in 1462 - is excerpted from Kritoboulos' History of Mehmed the Conqueror. At first glance, it seems that both accounts concern the division of the spoils of war into three parts $^{1}$. Without diminishing the similarity in the descriptions of distant events, such a feature is reminiscent of the use of topoi and the overuse of expressions and motifs inherent to Byzantine historians and chroniclers, which later authors, without amendments or with some additions, borrow from earlier works and include

\footnotetext{
${ }^{1}$ Ioannis Scylitzae Synopsis Historiarum, ed. I. Thurn, Berolini-Novi Eboraci 1973 [= CFHB, 5] (cetera: Skylitzes), p. 355.22-23; Critobuli Imbriotae Historiae, ed. D.R. ReInsch, Berolini-Novi Eboraci 1983 [= CFHB.SBe, 22] (cetera: Critobuli Imbriotae Historiae), p. 172.10-11. Cf. the accessible English translations: JoHn SKylitzes, A Synopsis of Byzantine History, 811-1057, trans. J. WorTley, Cambridge 2010, p. 337; Kritovoulos, History of Mehmed the Conqueror, trans. C.T. Riggs, Westport Conn. 1970 (cetera: Kritovoulos), p. 183.
} 
in their own texts. As explicitly stated, this feature in the construction of the text should not be considered a flaw, nor is it a definite proof of the unreliability of the descriptions ${ }^{2}$. All the more, those borrowings are usually not accidental and are prompted by various reasons. The demonstrations of education, the entry into tradition, the search for emphasis or the alignment with the built attitudes of the audience are only part of the ${ }^{3}$. With the clear idea that without literary and stylistic analysis, it is difficult (if not impossible) to achieve a complete and detailed study, the following lines are nevertheless the result of the temptation to examine briefly whether there really is a more significant degree of similarity or the resemblance is only in the phrase used.

\section{According to the Emperor's order}

The great war between the Byzantine Empire and the early medieval Bulgarian Tsardom, which continued from the 970s until the end of the second decade of the $11^{\text {th }}$ century and led to the fall of the Bulgarian lands under Byzantine rule, inevitably poses issues about the division of booty as well as the fate of the prisoners of war before the two fighting sides ${ }^{4}$. Indisputably, one of the most familiar

\footnotetext{
${ }^{2}$ K.J. Sinclair, War Writing in Middle Byzantine Historiography. Sources, Influences and Trends, Birmingham 2012 (unpublished PhD dissertation), p. 12-23; I. Nilsson, To Narrate the Events of the Past: On Byzantine Historians, and Historians on Byzantium, [in:] Byzantine Narrative. Papers in Honour of Roger Scot, ed. J. Burke et al., Melbourne 2006 [= BAus, 16], p. 47-58.

${ }^{3}$ Cf. P. Magdalino, Byzantine Historical Writing, 900-1400, [in:] The Oxford History of Historical Writing, vol. II, 400-1400, ed. S. Foot, C.F. Robinson, Oxford 2012, p. 218-237; J. Howard-Johnston, Historical Writing in Byzantium, Heidelberg 2014, p. 11-62; L. Neville, Guide to Byzantine Historical Writing, Cambridge 2018, p. 155-161, 308-311. See also: W. Treadgold, The Unwritten Rules for Writing Byzantine History, [in:] Proceedings of the 23rd International Congress of Byzantine Studies. Belgrade 22-27 August 2016. Plenary Papers. Belgrade 2016, ed. S. Marjanović-DušAnić, Belgrade 2016, p. 277-292; A. KALDELLIS, The Manufacture of History in the Later Tenth and Eleventh Centuries: Rhetorical Templates and Narrative Ontologies, [in:] Proceedings of the $23^{\text {rd }}$ International..., p. 293-306; J.S. CodoñER, Dates or Narrative? Looking for Structures in Middle Byzantine Historiography (9 $9^{\text {th }}$ to $11^{\text {th }}$ Century), [in:] Byzanz und das Abendland IV. Studia Byzantina-Occidentalia, ed. E. JuHÁsz, Budapest 2016, p. 227-255.

${ }^{4}$ At the end of the first and the dawn of the second millennium, the challenges associated with enemy fighters captured on the battlefield are far from new to the Bulgarian political elite and even less to the ruling circles in the Empire. Comments with the enclosed bibliography: A.J. ToynbeE, Relations with the Eastern Muslims; Appendix: Calendar of Exchanges of Prisoners between the Eastern Muslims and the East Roman Empire, [in:] IDEM, Constantine Porphyrogenitus and His World, Oxford 1973,

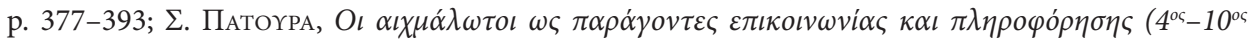

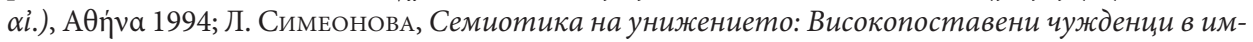
перската столица през X век, Род 4, 1996, p. 29-43; L. Simeonova, In the Depths of Tenth-Century Byzantine Ceremonial: the Treatment of Arab Prisoners of War at Imperial Banquets, BMGS 22, 1998, p. 75-104; A. Kolia-Dermitzaki, Some Remarks on the Fate of Prisoners of War in Byzantium ( $9^{\text {th }}-10^{\text {th }}$ Centuries), [in:] Atti del Congresso interdisciplinare di studi storici, ed. G. Gipollone, Città del Vaticano 2000 [= CAV, 46], p. 583-620; 'A. RAMADĀN, The Treatment of Arab Prisoners of War
} 
moments concerning the captured fighters is related to the fate of the Bulgarian warriors caught by the Byzantines after the Battle of Kleidion (July 29, 1014) ${ }^{5}$.

Attempts to trace the fate of Bulgarian captives caught by Byzantine hands in the late $10^{\text {th }}$ to the early $11^{\text {th }}$ century are directly dependent on the data in the written monuments of the epoch. A significant share of the information about what happened in the Byzantine-Bulgarian war of 971-1018 was scattered in texts that were the result of the creative activity of Byzantine authors from the end of the $10^{\text {th }}$ to the $12^{\text {th }}$ century. As a source of information, these narratives are supplemented by Armenian, Latin and Arabic texts, which contain many important details. Nevertheless, it should be pointed out that the various scattered notices in the historical sources related to the war-events are far from a strict, chronologically consistent, continuous, correct and profoundly compact narrative. Also, it must be put on the record that the available accounts about the prolonged series of clashes in the Byzantine-Bulgarian war of 971-1018 create a feeling that the majority of the military activities were outside of the areas where the main battles between the armies of the Bulgarian rulers and the Byzantine emperors happened earlier from the time of the $8^{\text {th }}$ century to the first decades of the $10^{\text {th }}$ century. This was very much due to the ruin of the original early medieval Bulgarian state center between the ridge of the Eastern Haemus Mountain and the Lower Danube River in 968-971. The capital Preslav, Pliska, Dorostolon and their surrounding settlements suffered quite a lot in the time of Sviatoslav of Kiev's Balkan campaigns

in Byzantium, $9^{\text {th }}-10^{\text {th }}$ Centuries, AIs 43, 2009, p. 155-194; Y. HRIstov, Prisoners of War in Early Me-

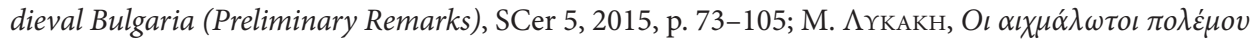

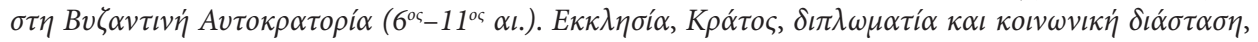

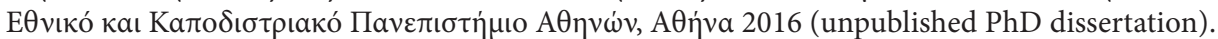

${ }^{5}$ The battle (and what happened after it) provokes considerable research interest. Its review within a single article is virtually impossible. However, there is a certain disparity and disagreements among the scholars about Tsar Samuel's warriors that were made blind, concerning the possible exaggerations of the number of mutilated people, and even about the general essence of the information pertaining to the victims of these atrocities. Cf.: В. ЗлАТАРСКИ, История на българската държава през средните векове, vol. I, p. 2, От славянизаиията на държавата до падането на Пьрвото изарство (852-1018), София 1927, p. 732-742; М. Wніттоw, The Making of Orthodox Byzantium, 600-1025, London 1996, p. 387-388; P. STEPHEnson, The Legend of Basil the Bulgar-Slayer, Cambridge 2003, p. 2-6, 33-34, 62-81ssq; C. Holmes, Basil II the Bulgar-slayer and the Blinding of 15,000 Bulgarians in 1014: Mutilation and Prisoners of War in the Middle Ages, [in:] How Fighting Ends. A History of Surrender, ed. H. Afflerbach, H. Strachan, Oxford 2012, p. 85-95; T. Томов, Биmката при Ключ през 1014 г., [in:] Европейският Югоизток през втората половина на X - началото на ХІ век. История и култура, еd. В. Гюзелев, Г.Н. Николов, София 2015, р. 142-169; P. SChreIner, Die vermeintliche Blendung. Zu den Ereignissen von Kleidion im Jahr 1014, [in:] Eвpoпейският Югоизток..., p. 170-190; А.М. Филипчук, Византийские подходы ХІ века к проблеме пленных: ослепление и убийство, ДВ 55, 2016, p. 330-333. Also, it should not be omitted that the bitterness of captivity has been repeatedly tested by various imperial warriors of every rank - the immediate participants in the battles. Cf.: Y. Hristov, A Glimpse at the Fate of the Byzantine Prisoners of War in Bulgaria during the Period from 976 to 1018, Епо 27.2, 2019, p. 406-414. 
and were additionally looted, destroyed and eventually occupied by the troops of Emperor John I Tzimiskes (969-976) in the course of a victorious Byzantine offensive against the Rus'. Despite all the heavy blows, including the deposition of the captured Bulgarian Tsar Boris II (969-971) in Constantinople, the Bulgarian state survived and relatively soon enough was reorganized in the western part of the Tsardom 6 .

At least in theory, the wider geographic scope of the conflict, its dynamics, the shifting of the border area, the notable exchange of victories and defeats on the battlefield as well as the deep raids makes the threat of falling into captivity very tangible and is capable of involving more direct participants in the whirlpool of events - even though (in general) the demographic, economic and military resources of the rivals are incomparable. Eventually, the Byzantine advantages severely changed the geopolitical situation after 1001-1004 and especially after the Battle of Kleidion. Undoubtedly, the Bulgarian resistance against the Imperial armies did not end in the last days of June 1014. It is well known that immediately after that the remnants of the Bulgarian army were reorganized by Tsar Samuel's son Gabriel Radomir. Under his command, the army of the Doux of Thessalonica Theophylact Botaneiates was destroyed. Thus, the strategic initiative of the Byzantines was broken and the breach in the defense of the Tsardom was actually closed. There were separate Bulgarian successes during the short reigns of Tsar Gabriel Radomir (1014-1015) and of Tsar Ivan Vladislav (1015-1018), but they did not change the general course of events, however, and did not prevent the fall of the Bulgarian lands under Byzantine rule ${ }^{7}$.

The seize of Longos Fortress took place in 1017 - in the final stages of the war, shortly before the falling of the First Bulgarian Tsardom. The Skylitzes' description of this event reads:

${ }^{6}$ The History of Leo the Deacon. Byzantine Military Expansion in the Tenth Century, ed. et trans. A.-M. Talbot, D.F. Sullivan, Washington D.C. 2005 [= DOS, 41], p. 128-131, 152-161, 177-201; Skylitzes, p. 276.23-277.37, 286.48-55, 287.91-291.99, 294.98-310.73; Памятники титературы Древней Руси. Начало русской титературы. ХІ - начало ХІІ века, еd. Д.С. ЛихАчев, Л.А. Дмитриев, Москва 1978, p. 78-88 (cf.: Повесть временных лет (по Лаврентьевскому списку 1377 года), trans. Д.С. Лихачев, О.В. Творогов, Санкт-Петербург 2012, p. 44-51). See also: S. Franklin, J. Shepard, The Emergence of Rus, 750-1200, London-New York 1996, p. 145-151; И. Божилов, В. Гюзелев, История на България в 3 тома, vol. I, История на средновековна България VII-XIV век, София 1999, р. 308-318; П. ПАвлов, Борис и Роман - трагедията на иарския род в края на Х век, [in:] IDEм, Забравени и неразбрани. Събития и личности от Българското средновековие, София 2012, p. 53-83. For the far more non-centralized character of the Bulgarian state under the rule of Samuel and his successors, especially compared with the previous forms of the provincial and military organization: G.N. Nikolov, The Bulgarian Aristocracy in the War against the Byzantine Empire (971-1019), BSC 3, 2001, p. 141-158; Г.Н. Николов, Централизбм и регионализбм в ранносредновековна България (края на VII - началото на XI в.), София 2005, p. 123-166.

${ }^{7}$ Skylitzes, p. 350.59-351.81 (cf.: trans. J. Wortley, p. 332-333). 
...AM 6524, fourteenth year of the indiction, the emperor left the capital and went to Triaditza where he encamped before the fortress of Pernikos and besieged it, but those within resisted with endurance and determination; many Romans fell. When the siege had dragged on for eighty-eight days, he realized there was no possibility of succeeding so he withdrew, empty-handed, and fell back on Mosynoupolis. There he rested his army then, at the beginning of spring, he marched out of Mosynoupolis and entered Bulgaria. He encamped at the fortress called Longos and took it by siege. He sent David Areianates and Constantine Diogenes to the plains of Pelagonia and took possession of many beasts and numerous prisoners. The Emperor burnt the fortress when it was taken and divided the spoils of war into three parts. One part he assigned to the Russian allies; a second part to the Romans; the third he kept for himself. Then he advanced further and came to Kastoria, but having made an attempt on the city he concluded that it was inexpugnable and turned back... ${ }^{8}$

Paying attention to the specific passage concerning the captured prisoners and the distribution of military prey, it should be explicitly pointed out that such a significant aspect did not remain untouched by the legislative efforts during the Middle Byzantine era. In Ecloga XVIII, 1 of the Emperors Leo III (717-741) and Constantine V (741-775), it was stated that the share reserved for the state treasure was one sixth and the rest was shared in equal parts between the participants in the march. The additional material stimulation of those distinguished with bravery and dedication in the military activities is at the discretion of the commander and is at the expense of the part designated for the Treasury. It is not accidental that those provisions of the $8^{\text {th }}$ century Isaurian legislation were incorporated in legal compilations at the time of Emperor Basil I (867-886) and his successor Emperor Leo VI (886-912) ${ }^{9}$. A close look at the aforementioned title of the Ecloga and at the corresponding passages in the later Procheiros Nomos, Eisagoge and Basilika raises the notion that it is rather about outfits and valuables collected from the fallen enemies on the battlefield. The grounds of such a claim are rooted not only in the vocabulary used by the legislator ( $\sigma \kappa \dot{\lambda} \lambda$ ov - military equipment stripped off from a slain enemy; booty; spoil) ${ }^{10}$. They are additionally

\footnotetext{
${ }^{8}$ Skylitzes, p. 355.11-26, trans. J. Wortley, p. 336-337.

${ }^{9}$ Эклога, Византийский законодательны свод VIII века, ed. et trans. Е.Э. Липшиц, Москва 1965,

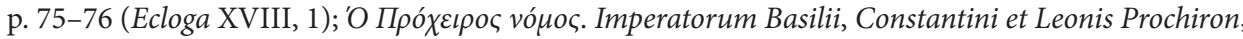

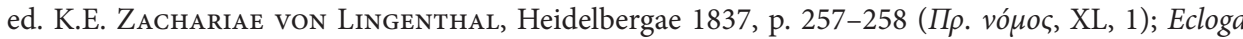
Leonis et Constantini, Epanagoge Basilii Leonis et Alexandri, ed. K.E. ZaChariaE VON LingenthaL,

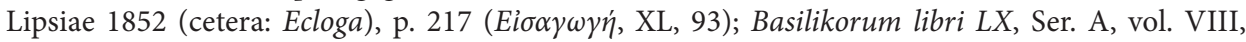

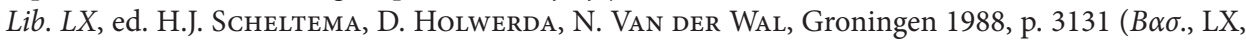
Appendix).

${ }^{10}$ Cf.: $\sigma \kappa v \dot{\lambda} \varepsilon v \mu \alpha$ - armours taken from a dead enemy; trophies; $\sigma \kappa v \bar{\lambda} \varepsilon v ́ \omega$ - stripping off weapons, armours and equipment from killed enemies; looting; pillaging; plundering. - Старогръцко-български речник, ed. М. Войнов, Д. Дечев, В. Георгиев, А. Милев, Б. Геров, М. Тонев, ${ }^{2}$ София 1943, p. 773-774; Древнегреческо-русский словарь, vol. II, M- $\Omega$, ed. И.Х. ДворецКИй, Москва 1958, p. 1486-1487; LSJ, p. 1617. The warriors' temptation as well as their chase for $\sigma \kappa \bar{\nu} \lambda \alpha$ (booty) should not be underestimated at all. As it has been pointed out the collected booty, along with the
} 
supplemented by the fact that the provisions in question do not specify principles that should be observed in captives' distribution between the participants in the military activities.

On the other hand, the idea of rewarding the soldiers who participated in the fighting is an essential issue in the military manuals from the $10^{\text {th }}$ century and gives an important additional viewpoint. The understandable interest in the loot and the captives was so significant that it could cause problems with the discipline and a failure in the tactical plans of the Army command. Not surprisingly, within the texts of several military manuals there are punishments prescribed for derelictions of duty in order to collect booty ${ }^{11}$. In these texts, the central government's interest in securing the share for the Imperial Treasury can be easily seen. They also leave no place for any serious doubts that enslaved captives - in the broad medieval sense that includes both the regular soldiers and the various higher ranks as well as the civilians of different age, sex, skills and social status - were a particularly desirable share of prey from everyone in the victorious army. Interestingly, it has been pointed out recently that between the well-known Tactica of Emperor Leo VI and Sylloge Tacticorum, there is a discrepancy in the amount allocated to the Treasury (respectively $1 / 5$ and $1 / 6$ ), which is a reason to believe that the regulations changed over time. In this regard, it seems that we encounter not so much a fixed standard for sharing the booty (regardless of the possible distribution of captives) but the flexibility and practicality frequently shown by the Byzantine authorities ${ }^{12}$. Here it also must be born in mind that sometimes it is precisely the prisoners' special

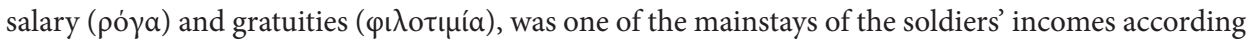
to Ecloga XVI, 2 - E. McGeer, Sowing the Dragon's Teeth. Byzantine Warfare in the Tenth Century, Washington D.C. 1995 [= DOS 33], p. 321, n. 76.

${ }^{11}$ With the enclosed comments and bibliography: E. McGeer, Sowing the Dragon's Teeth..., p. 320 329. See also the article of the Polish scholar Szymon Wierzbiński: S. Wierzbiński, Prospective Gain or Actual Cost? Arab Civilian and Military Captives in the Light of Byzantine Narrative Sources and Military Manuals from the $10^{\text {th }}$ Century, SCer 8, 2018, p. 253-283 (p. 262-263 in particular).

${ }^{12}$ S. Wierzbiński, Prospective Gain..., p. 265, n. 93. Cf. Leonis VI Tactica, XVI, 4; XX, 192, ed. et trans. G. Dennis, Washington D.C. 2010 [= CFHB, 49] (cetera: Leo VI), p. 382-385, 604-605; A Tenth-century Byzantine Military Manual. The Sylloge Tacticorum, trans. G. Chatzelis, J. Harris, London 2017 [= BBOS, 22] (cetera: Sylloge Tacticorum), L. 4; L. 6, p. 84-85. See also: A. DAIN, Le Partage du butin de guerre d'après les traités juridiques et militaires, [in:] Actes du VI Congrès international d'études byzantines, vol. I, Paris 1950, p. 347-354; В.В. КучмА, Военная организация Византийской империи, Санкт-Петербург 2001, p. 323-325. It was emphasized that there is no disagreement in Sylloge Tacticorum L. 4. and L. 6. with the principles that laid down in Ecloga XVIII,

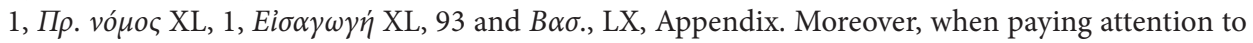
the information coming from one or another Byzantine military manual, it is necessary to take into account not only the impact of the legislation in force in the Empire, but also to pay tribute to other possible influences. For example, the 1/5 share allocated to the Treasury under the Leo VI finds an interesting and precise parallel among the Islamic legal regulations concerning the division of spoils of war. Cf.: M. KHAdDuRI, War and Peace in the Law of Islam, Baltimore 1955, p. 121. 
value that causes their separation from other booty, and as a result, they are not always included in the general division of the so-called "gifts of victory". In regards the fair distribution of spoils of war, it must be put on the record that the isolation of ordinary warriors from access to the booty is generally perceived as unusual (as well as an unexpected or excessive generosity of the commander to the soldiers).

When we talk about the conflict between Byzantium and Bulgaria from the late $10^{\text {th }}$ to the early $11^{\text {th }}$ century, it seems necessary to mention at least briefly some aspects of its perception, motivation and ideological justification, especially within the Empire, that mark both the fate of the Bulgarians that fell into Byzantine captivity and the descriptions of the events in the various type of narratives. Of course, the ruling circles in Constantinople in the age of the emperors of the Macedonian dynasty were not reluctant to the idea of avoiding collisions with Orthodox co-religionists. However, even after the Christianization in the 860 s, despite the extended periods of lull, Bulgaria continued to be the main adversary of Byzantium in the Balkans until the beginning of $11^{\text {th }}$ century. The tensions that caused atrocities, mutilations and kidnappings can be considered at least in part as a continuation of the inertia accumulated by the wars between the two states before the conversion of the Bulgarians $s^{13}$.

Despite the relatively short description, Skylitzes' text indicates that the prey was significant and diverse, and that, apart from livestock (and valuables? - YH, VK), many captives fell in Byzantine hands, including both abducted non-combatants from the Pelagonia region and the permanent inhabitants of the fortress - warriors and civilians and their families. In addition, it is not specified that all three partitions are identical in size and variety. However, a certain guideline can be found due to the fact that under conditions of prolonged conflicts at that time, the Emperor Basil II hardly resisted the temptation to acquire additional profits by kidnapping as many residents as possible from the Bulgarian territory as well as integrating captured warriors into his own armies. In his Synopsis historiarum, Skylitzes indisputably indicates that the Emperor Basil II did not hesitate to resettle

${ }^{13}$ I. Stouraitis, Byzantine War against Christians - an "Emphylios Polemos"?, B $\Sigma$ v 2 20, 2010, p. 85110. See also: A. Laiou, On Just War in Byzantium, [in:] To Hellenikon. Studies in Honor of Speros Vryonis Jr., vol. I, ed. S. Reinert, J. Langdon, A. Allen, New Rochelle-New York 1993, p. 153-174 (= A. Laiou, On Just War in Byzantium, [in:] Byzantine Warfare, p. I.2, ed. J. Haldon, Aldershot 2007, p. 153-174); J. Haldon, Warfare, State and Society in the Byzantine World, 565-1204, London 1999, p. 13-33; W. Treadgold, Byzantium, the Reluctant Warrior, [in:] Noble Ideals and Bloody Realities. Warfare in the Middle Ages, ed. N. Christie, M. YAZIgi, Leiden-Boston 2006, p. 209-233; J. Koder, I. Stouraitis, Byzantine Approaches to Warfare ( $6^{\text {th }}-12^{\text {th }}$ Centuries). An Introduction, [in:] Byzantine War Ideology between Roman Imperial Concept and Christian Religion, ed. IIDEM, Vienna 2012, p. 9-15; I. Stouraitis, 'Just War' and 'Holy War' in the Middle Ages. Rethinking Theory through the Byzantine Case-Study, JÖВ 62, 2012, p. 227-264. Also pay attention to: С. Пириватрит, Самуилова држава. Обим и карактер, Београд 1997, p. 120-132; C. Holmes, Basil II the Bulgarslayer..., p. 85-95; А.М. Филипчук, Византийские подходы..., p. 330-340. 
the Bulgarian captives in Byzantine provinces ${ }^{14}$. The example with the population of the fortress of Moglena is highly illustrative. In 1015, a large number of soldiers along with the Kavkhan Dometian and many of other Bulgarian boyars were taken into captivity.

...[The Emperor Basil II - YH, VK] sent the patrician Nikeohoros Xiphias and Constantine Diogenes... into the region of Moglena with an army. The Emperor arrived when they ravaged the whole area and were besieging the city - wrote John Skylitzes - He diverted the river that flows by the city and excavated the foundations of the walls. Wood and other combustible materials were put into excavations and set fire; as the fuel burnt, the walls came down. When those within saw this, they fell to prayers and groans, surrendering themselves together with the fortress. Dometianos Kaukanos, a powerful man and an advisor of Gabriel, was captured; also Elitzes, the governor of Moglena, many important people and a considerable number of fighting men. The Emperor sent those capable of bearing arms to Asprakania (i.e., Vaspurakan, Eastern Asia Minor)... ${ }^{15}$

Of course, it should be acknowledged that there is no mention of deportation and integration in the story of the capture of Longos and the plundering of the surrounding area. Nevertheless, with the necessary caution, it may be assumed that the part retained by the Emperor himself includes at least boyars and soldiers (as in the case of Moglena). Furthermore, given to the well-known distribution among the soldiers of one hundred kentenaria of gold coins from the Bulgarian Tsar's treasury in 1018, the remaining two parts of Longos' booty are probably composed of valuable goods and livestock. There seems to be more uncertainty in the attempts to guess the fate of captured non-combatants. Hesitations are not due to the lack of opportunity for their deportation and resettlement in the Byzantine provinces - either as free, or as dependent peasants, with the respective taxation, duties and obligations. Rather it is due to the possibility of their enslavement. Moreover, following the description of the partitioning in question, there can be no denial of any captives' presence in these parts of booty reserved for the Byzantine warriors or for the important Russian auxiliaries ${ }^{16}$.

${ }^{14}$ Cf. for example: ... Then the Emperor marched into Thessaly and rebuilt the fortresses which Samuel had overturned; the ones they held he besieged and transported the Bulgarians to a place called Boleron...; also ...At the beginning of spring [the Emperor] returned to Bulgaria again and headed for the fortress of Vodena, for the people there had broken faith with him and taken up arms against the Romans. By a long-drawn-out siege he forced those within (when they had received assurances to surrender themselves). He deported them again to Boleron... - SKYLITZES, p. 344.16-19, 352.9-13, trans. J. WORTLEY, p. 327, 333.

${ }^{15}$ Skylitzes, p. 352.23-37, trans. J. Wortley, p. 334. However, the rest of the remaining mass of people were not so lucky and according to the Emperor's order became subject of pillage and rapine. ${ }^{16}$ As a rule, the enslavement of Orthodox co-religionists must be avoided. However, as regards those captured in wartime there are enough cases of exception. Cf.: Y. Rotman, Byzantine Slavery and the Mediterranean World, trans. J.M. TodD, Cambridge Mass.-London 2009; G. Prinzing, On Slaves and Slavery, [in:] The Byzantine World, ed. P. StePhenson, London-New York 2010, p. 92-102; IDEM, Slavery in Byzantium from 566 until 1453, [in:] Proceedings of the 23 $3^{\text {rd }}$ International Congress 
Taking into consideration the characteristics mentioned, a question arises whether the division into three parts in 1017 carried out by an order of Emperor Basil II was recorded by Skylitzes (decades later in the late $11^{\text {th }}$ century) precisely because it seems more special or unusual. The answer cannot stand isolated from the peculiarities of the Synopsis historiarum pertaining to warfare. As it has been pointed out ...Skylitzes was writing with an educative rather than descriptive purpose in mind. In this sense Skylitzes' handling of military matters was not about individual events or people in recorded time or place, but about the articulation of general military principles exemplified in narrative action... and the great multitude of various military narratives within the frames of his text ...would make best sense not as stories significant to the history of the times they describe, but instead as rhetorical tools that serve contemporary educative aims ${ }^{17}$. In this regard, without underestimating the historicism in the story about the capture of Longos, it is helpful to think through the prism of the impressions that the author made through the passage in question of Synopsis historiarum - especially because of the presence of distinct and significant pre-organized detachments of foreigners in the Byzantine armies and the problem with their remuneration and satisfaction of their interest in the loot. The importance of such a matter increases from the mid- $11^{\text {th }}$ century onwards, in view of the changes in the Imperial armies and the decisive presence of foreign mercenary units ${ }^{18}$.

\section{The growing shadow of the crescent}

The second historical event, to which some brief touches are dedicated in this paper, is the division of the inhabitants of Mytilene - the main city of the island of Lesbos - during the Ottoman campaign in 1462. More than a century earlier,

of Byzantine Studies. Belgrade, 22-27 August 2016. Round Tables, ed. B. Krsmanović, L. Milanović, Belgrade 2016, p. 176-181. Actually, this fragment of the Synopsis historiarum is used as an evidence for the enslavement of the Bulgarian captives in the late $10^{\text {th }}$ - the early $11^{\text {th }}$ century. Vide with the

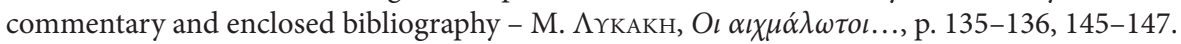

${ }^{17}$ C. Holmes, The Rhetorical Structures of John Skylitzes' Synopsis Historion, [in:] Rhetoric in Byzantium. Papers from the Thirty-fifth Spring Symposium of Byzantine Studies, Exeter College, University of Oxford, March 2001, ed. E. Jefrreys, Aldershot 2003, p. 196. See also: M. Mullet, Aristocracy and Patronage in the Literary Circles of Comnenian Constantinople, [in:] The Byzantine Aristocracy, IX to XIII Centuries, ed. M. Angold, Oxford 1984, p. 173-187; C. RouechÉ, Byzantine Writers and Readers: Storytelling in the Eleventh Century, [in:] The Greek Novel, A.D. 1-1985, ed. R. BEaton, London 1987, p. 123-133; B. CRоке, Uncovering Byzantium's Historiographical Audience, [in:] History as Literature in Byzantium. Papers from the Fortieth Spring Symposium of Byzantine Studies, University of Birmingham, April 2007, ed. R. MACRIDES, Farnham 2010 [= SPBSP, 15], p. 25-53 (p. 46-50 in particular); C. Holmes, Basil II and the Governance of Empire (976-1025), Oxford 2005, p. 118-119, 162-170, 172-239.

${ }^{18}$ For many examples of division and distribution of the loot, including shares for the Treasury, for their own warriors and for the squads of foreign mercenaries see: S. KYRIAKIDIs, The Division of Booty in Late Byzantium (1204-1453), JÖB 59, 2009, p. 163-175. 
in 1355, the island of Lesbos passed into the hands of the ambitious Genoese captain Francesco Gattilusio. He gained power over the island as a reward for assisting Emperor John V Palaeologus in the overthrow of John Cantacuzenus. The Genoese adventurer became even closer to the Palaeologos dynasty via his marriage to the sister of Emperor John V. As a brother-in-law of the Emperor and being an Archon of Lesbos, Francesco Gattilusio was inevitably caught up in the conflicts of the region for the coming decades. Despite the turbulent atmosphere, and even in the face of an open conflict between Venice and Genoa, the Gattilusio family not only did not suffer any damage, but managed to maintain their strategic and economically lucrative ownership, even expanding their power in the Aegean ${ }^{19}$. In not very clear circumstances, Francesco took control over Old Phocaea, while New Phocaea continued to be under the rule of Genoa. An even more significant acquisition was achieved in 1382 when control was established over Ainos. Until then, this important town along the Thracian coast at the mouth of the Maritsa River was under Byzantine rule, although its surrounding area was devastated and conquered by the Ottomans. Probably as a result of the tensions between the recent allies and as part of the compromises, the reign in Ainos was taken over by Niccolo, brother of Archon Francesco I Gattilusio in 1384. As noted, from that moment on, the Principality of Gattilusio began to develop as a collection of coastal port enclaves and island possessions in the Aegean, often entrusted to various representatives of the family, under the nominal rule of the Archon of Lesbos. From the early 1430s-1440s, Gattilusio's possessions in Northern Aegean were extended and included the islands of Samothrace and Thasos. Despite a clever policy and that kept the Gattilusio family away from the Crusading activities, the great military endeavors and political transformations in the Eastern Mediterranean in the second decade of the $15^{\text {th }}$ century did not miss their Aegean principality. The Lesbos' Archon Dorino accepted the obligation to pay an annual tribute to the Ottomans in order to avoid any hostility toward his possessions as well as to avert the devastating attacks of the sultan's nav $y^{20}$. Thanks to their political flair and their familiarity with the situation in the region, the members of the Gattilusio family were very quick-witted and relatively successful in the course of the siege of Constantinople and immediately after the conquest of the town. Despite the decades of joint ventures and dynastic relations with Palaeologus, the members of the Gattilusio family did not attempt to participate in the defense of Constantinople.

\footnotetext{
${ }^{19}$ C. Wright, Byzantine Authority and Latin Rule in the Gattilusio Lordships, [in:] Byzantines, Latins, and Turks in the Eastern Mediterranean World after 1150, ed. J. Harris, C. Holmes, E. Russell, Oxford 2012, p. 247-263; F. Kondyli, Lords at the End of the Empire: Negotiating Power in the Late Byzantine Frontiers (Fourteenth-Fifteenth Centuries), ABSA 112, 2017, p. 309-339 (p. 327-335 in particular).

${ }^{20}$ C. Wright, The Gattilusio Lordships and the Aegean World, 1355-1462, Leiden-Boston 2014 [= MMe, 100], p. 29-66; P. Edbury, Christians and Muslims in the Eastern Mediterranean, [in:] The New Cambridge Medieval History, vol. VI, ed. M. JonEs, Cambridge 2000, p. 864-884.
} 
Instead, they sent their representatives to the Court of the triumphant Mehmed II to demonstrate their loyalty and obedience. It was not accidental that the Sultan agreed with Dorino from Lesbos and Palamede from Ainos to obtain power over the islands of Lemnos and Imbros (under the Byzantine authority until May 1453) in exchange for the disbursement of tribute. If we trust Kritoboulos, this was done with the assistance of the local population. As for Lemnos, Dorino had certain positions, as he owned the Kotzinos fortress and took the opportunity to subdue the whole island. At that particular moment, this decision proved acceptable for the Ottomans as well, especially given the danger of Venetian expansion in the Aegean. Such a development was not excluded at all, and the considerations that urged Sultan Mehmed II to show benevolence to the representatives of the eminent Genoese family were confirmed by the Venetian occupation of the islands of Skyros, Skiathos and Skopelos ${ }^{21}$.

The success of Gattilusio was fleeting. In the summer of 1455 Domenico (the eldest son of Dorino) was forced to appear in person in the Ottoman court to be given the hereditary rights over Lesbos. According to the information of Doukas, he was forced to surrender the Thassos to the Ottomans. In addition, in front of Viziers Said Ahmed Pasha and Mahmud Pasha, he desperately negotiated to reduce the sum of the tribute doubled at the request of Sultan Mehmed $\mathrm{II}^{22}$. At the end of that year, with the capture of the Old Phocaea, the Ottomans deprived Domenico from another one of his possessions. At the beginning of the next year, 1456, the Genoese family suffered new losses after the surrender of Ainos and the occupation of the islands of Imbros and Samothrace, and several months later Gattilusio lost power over Lemnos as well. In the summer of 1457, the fleet of Sul$\tan$ Mehmed II attacked the second-most important city on the island of Lesbos - Mithymna. The attackers were repulsed and suffered significant losses before retreating to Gallipoli. Under the circumstances of the continuous bloodshed and Ottoman advance on the Balkans as well as in Aegean Sea, the last Archons of Lesbos made several attempts to seek help. However, neither Genoa itself, nor the Papacy or any other Western partners managed to provide vital reinforcements and support ${ }^{23}$.

\footnotetext{
${ }^{21}$ Critobuli Imbriotae Historiae, p. 85.4-87.3 (cf.: Kritovoulos, p. 85-87); DoukAs, Decline and Fall of Byzantium to the Ottoman Turks, trans. H. Magoulias, Detroit 1975, p. 241 (Dukas, Historia Turcobyzantina, ed. V. Grecu, Bucharest 1958 (cetera: Dukas), p. 395.14-20); Laonikos ChalkoKondyles, The Histories, trans. A. Kaldellis, Cambridge Mass.-London 2014 (cetera: LaOnikos Снацкокоndyles), p. 400-403. See also: К. Имьър, Османската империя 1300-1481, София 2000, p. 226-235, 240-242, 256-258.

${ }^{22}$ Dukas, p. 413.16-415.7 (cf.: Decline and Fall of Byzantium..., p. 251).

${ }^{23}$ M. Balard, The Genoese in the Aegean (1204-1566), MHR 4, 1989, p. 158-174; C. Wright, The Gattilusio Lordships..., p. 65-69; K. FleEt, Ottoman Expansion in the Mediterranean, [in:] The Cambridge History of Turkey, vol. II, The Ottoman Empire as a World Power, 1453-1603, ed. S. FARUQHI, K. FLEET, Cambridge 2012, p. 141-143.
} 
The final (well-prepared and severely outnumbered) Ottoman attack against Lesbos took place in September 1462. Following the Sultan's orders, Mahmud Pasha arrived at Lesbos with a large fleet and attempted to persuade the defenders to surrender without resistance. Meanwhile, Sultan Mehmed II already arrived at the Anatolian coast in front of the island. Archon Niccolo Gattilusio refused to surrender and the Ottomans started the siege of Mytilene. In his History of Mehmed the Conqueror, Kritoboulos left a vivid contemporary description of the fortress' surrender and the following events:

\begin{abstract}
$\$ 80 . .$. Those in the city and their commander, when they saw that the Sultan had crossed over and that the army was ready to attack them by land and sea, feared that they would be captured by assault. They saw that the wall was demolished by the cannon and that the army was immense and strong and fully armed, and also that the attack by the Sultan was irresistible and that he would never leave the island until he had completely subdued it. So they sent a messenger to offer their surrender and that of the city to the Sultan, and also to beg for forgiveness because they had not yielded immediately when summoned.
\end{abstract}

$\$ 81$. The Sultan received these men and gave them pledges. Accordingly, the Mitylenians came out of their city with their commander, made obeisance before the Sultan, and surrendered the city to him...

$\$ 82$. After spending four whole days on the island, inspecting it and everything in it and admiring its size and beauty and the various advantages of the country and its arrangement, the Sultan then embarked in a trireme and crossed over his camp, leaving Mahmud to arrange affairs in the city and throughout the island according to his instructions.

$\$ 83$. Mahmud gathered all the inhabitants of the city, men, women and children, and divided them into three parts. The first part he allowed to stay in the city and inhabit it, retaining and enjoying their own property and playing the customary yearly tribute. The second he deported to Constantinople and settled there. And the third he made slaves and distributed to the soldiers. As many mercenaries of the Italians as he found in the city, he killed every one ${ }^{24}$.

Taking into consideration the Kritoboulos' account, it seems worth remembering the Islamic legal concepts concerning military prey. As it has been pointed out, the term spoil (ghanima) is applied specifically to property acquired by force from non-Muslims. It includes, however, not only property (movable and immovable) but also persons, whether in the capacity of asra (male combatants = prisoners of war) or sabi (kidnapped women and children). The element of force ('anwatan) and the imām's permission are essential... The imām's permission formalizes fighting as the fulfilment of the jihäd duty and invokes the law governing the conduct of fighting as well as the acquisition and the division of the spoil among those who have right to $i t^{25}$. Despite some differences in the interpretations and/or the demonstrated preferences, the view of the Islamic legal regulations regarding the captives notes

\footnotetext{
${ }^{24}$ Kritovoulos, p. 183-184.

${ }^{25}$ M. Khadduri, War and Peace..., p. 119.
} 
the presence of four possibilities: execution, slavery, liberation (less often unpaid and more often provided they will pay jizyah [poll-tax]) and ransom (including cash and/or valuables, as well as exchange) ${ }^{26}$. On the other hand, it is no less important that by the third quarter of the $15^{\text {th }}$ century the Ottomans already gained their own vast experience in deriving dividends from captured enemy soldiers and abducted civilian populations ${ }^{27}$.

Without neglecting or minimizing the historical accounts of what happened with the captured warriors and civilians in Constantinople after its conquest by Sultan Mehmed II, it looks like that the records concerning the Ottoman military actions in the Western Balkans, in the Peloponnese, in the Aegean and Asia Minor and the clashes with Hungary and Venice in the decades after 1453 are more useful. The mid-1450s and the early 1460 s are marked by new Ottoman successes. The sources describing the conquest of the Peloponnese from 1458 to 1460 repeatedly recount the fate of those who fell in Ottoman captivity. In the Memoirs of a Janissary, it is stated that execution often is the practice applied to the enemy soldiers captured by the Ottomans. Kritoboulos attempted to bind such actions in particular to the forcibly seized fortresses in the Peloponnese, held by the Albanian settlers, although he did not hide that this actions were also linked to the Sultan's

${ }^{26}$ B. Bertosa, The Treatment of Prisoners of War and Non-Combatants in Quran, CMJ 8.1, 2007, p. 19-26 [Web Access: http://www.journal.forces.gc.ca/vo8/no1/bertosa-eng.asp]; L. SALAYMEH, Early Islamic Legal-Historical Precedents: Prisoners of War, LHR 26.3, 2008, p. 521-544; M. MuniR, Debates on the Rights of Prisoners of War in Islamic Law, ISt 49.4, 2010, p. 463-492.

${ }^{27}$ When the Ottoman state was growing from an Anatolian beylik to a prime political power in the Eastern Mediterranean, the Islamic concept of jihäd was intertwined in favour of the expansion. At a relatively early stage, the impulses of the nomadic Turkmen $a k m$, without limiting or redirecting the desire for prey, were used and transformed into ghazā. Of course, with the proviso that generalizations can be misleading, it is also good to consider the evolution of Ottoman warfare from the $14^{\text {th }}$ through the first half of the $15^{\text {th }}$ century and especially the nature, peculiarities and intensity of the military marches of Sultan Mehmed II on land and sea. The information available in the records leaves no room for doubt that there is no way to define the conquest of Lesbos as a consequence of a successful plundering raid. The fall of the important Aegean island under Ottoman rule happens after a large-scale campaign, with the participation of well-prepared and equipped units, which is very different from the devastating raiding for booty, undertaken by much more maneuverable units, but usually more modest in number. Cf.: H. İNALCiK, Ottoman Methods of Conquest, [in:] IDEM, The Ottoman Empire. Conquest, Organization and Economy. Collected Studies, p. 1, London 1978, p. 104-129; G. Kaldy-Nagy, The Holy War (jihad) in the First Centuries of the Ottoman Empire, HUS 3-4, 1979-1980, p. 467-473; R. Jennings, Some Thoughts on the Gazi-Thesis, WZKM 76, 1986, p. 151-161; C. Kafadar, Between Two Worlds. The Construction of the Ottoman State, Berkley 1995; C. Heywood, The Frontier in Ottoman History: Old Ideas and New Myths, [in:] Frontiers in Question. Eurasian Borderlands, 700-1700, ed. D. Power, N. Standen, London 1999, p. 228-249; Х. Иналджък, Османската империя. Класическият период 1300-1600, София 2002, p. 19-25; P. Fodor, Ottoman Warfare, 1300-1453, [in:] The Cambridge History of Turkey, vol. II, Byzantium to Turkey, ed. K. Fleet, Cambridge 2009, p. 192-226; D. Kastritsis, Conquest and Political Legitimation in the Early Ottoman Empire, [in:] Byzantines, Latins, and Turks in the Eastern Mediterranean after 1150, ed. J. Harris, C. Holmes, E. Russell, Oxford 2012, p. 221-263. 
strategic plans aimed at the imposition of fear, discouragement and denial of resistance ${ }^{28}$. Like the Late Byzantine chronicler from Imbros, his contemporary Tursun Beg wrote that in the Ottoman campaigns from the late 1450s and the early 1460s the men in the fortresses taken by force were killed and the women and children were enslaved ${ }^{29}$. However, one should not underestimate the evidence that the pogroms sometimes went far beyond. The notifications of other contemporaries and witnesses to the events, such as Sphrantzes and Chalkokondyles, leave a clear feeling that the executions affected not only the soldiers who resisted and the men fit to carry weapons, but also defenseless women, children and old men. Chalkokondyles also adds details about the fact that voluntary surrender did not always save people from the unhappy fate of captivity and the horror of the mayhem ${ }^{30}$. The direct link between the merciless attitude towards the captured by the Ottomans on the one hand, and the specific character of some particularly fierce hostilities on the other, stands out distinctly in the information about the campaign of Sultan Mehmed II against the Wallachian prince Vlad the Impaler in $1462^{31}$.

${ }^{28}$ Konstantin Minailović, Memoirs of a Janissary, ed. et trans. B. Stolz, S. Soucek, Ann Arbor 1975 [= MST, 3] (cetera: Konstantin Mihailović), p. 113. The cases of mass executions cannot be underestimated at all. However, along with the information about the subjugation, there are also passages in which a deportation of large groups and their resettlement after 1453 in the conquered by Mehmed II Constantinople (and also about the selection of young men to replenish the Janissary Corps) is mentioned. Cf.: KRITovoulos, p. 105, 133, 136, 139-140, 148-149, 154-156 (cf.: Critobuli Imbriotae Historiae, p. 101.16-2, 126.1-8, 128.2-5, 131.11-18, 139.12-140.5, 144.22-147.15); Decline and Fall of Byzantium..., p. 243, 257-258 (cf.: DukAs, p. 399.1-8, 425.13-427.7). Quite interesting are the descriptions about the capitulation of Novo Bardo in 1455. All the residents of the surrendered city are forced to leave their property and while the other exits are blocked, to go before the Sultan through a single left open gate of the surrounded city and be subjected to selection by gender, age and social status. All those among the men who were the most important and distinguished he ordered decapitated. - the text reads - The remainder he [Sultan Mehmed II] ordered released to the city. As for their possessions, nothing of theirs was harmed. The boys were 320 in number and the females 74. The females he distributed among the heathens, but he took the boys for himself into the Janissaries, and sent them beyond the sea to Anatolia, where their preserve is. - Konstantin Minailović, p. 99.

${ }^{29}$ Tursun Beg, The History of Mehmed the Conqueror, ed. et trans. H. Inalcik, R. Murphey, Minneapolis-Chicago 1978 (cetera: Tursun Beg), p. 43-44.

${ }^{30}$ Георгије Сфраниес, Хроника, ed. et trans. М. Станковић, Београд 2011 (cetera: Георгије Сфранuеc), p. 171, 177, 181-187; Laonikos Снацкокоndyles, p. 316-317, 322-339, 342-343, 364-367. ${ }^{31}$ Tursun Beg describes that war as a great success for the Sultan, whose camp is ...overflowing with booty, young girls and boys, and captives... Cf.: TuRsun BEG, p. 48-49. However, other authors are far from being so categorical. For example, Doukas writes about the difficulties, the worries, the great losses of the Ottomans and the humiliating return of the Sultan to Edirne. Kritoboulos also notes the material damage suffered and the loss of harnessed animals during the night attack of the troops of Vlad the Impaler. Constantine Mikhailovich (who was a participant in the campaign) writes about an atmosphere of fear in the Sultan's camp, and also points out that during the mentioned Wallachian attack the Ottomans suffered not only great material losses, but also lost many people. In the panic that ensued, various units of the Sultan's army mistakenly fought against each other. In addition, in an attempt to repel the forces of Vlad III, the Janissaries quite deliberately killed other Ottoman soldiers. 
Judging by the information that had come to us, the extent of the terror, the deliberate cruelty of mass massacres, enslavements and deportations were even more extensive and outrageous in the 1460s during the suppression of the resistance led by George Kastrioti (Skanderbeg) and the final subjugation of the Albanian lands ${ }^{32}$.

Given the above-mentioned, there can be no doubt in the statement that the subjugation of Lesbos in 1462 was not so violent and less bloody than Ottoman campaigns in Morea, Wallachia and Albanian lands. In this regard, the descriptions of the conquest of Bosnia in 1463 offer a very close parallel to what was happening on the Aegean island in the autumn of the previous year. Bozovac was conquered at the beginning of hostilities after a short siege.

He [Sultan Mehmed II] terrified the townspeople with his cannons, both the horizontal ones and the upturned mortars, and he subjected the city. - One can read in Chalkokondyles' chronicle - He left part of its people there, gave another part to the leading Turks, and sent the third to Byzantion [i.e. - Constantinople - YH, VK]. He then ordered Mahmud [the Grand Vizier] to pick the best men from the army of Europe [Rumeli] and go from Bobovac to wherever he learned the king of the Illyrians [Bosnians] was residing... ${ }^{33}$

Afterwards, in charge of the Rumeli army, Mahmud Pasha marched through the country with a marked haste. The Ottoman Grand Vizier first arrived at Jajce and then turned towards the Sokol in pursuit of King Stjepan Tomašević only to discover that the Bosnian ruler had fled at Ključ already. Taking into consideration the dangerous mountain terrain, the fortress mentioned was definitely not among the easily accessible ones. To make Ključ even more inaccessible and

- Konstantin Mihailović, p. 129-133. See also: Decline and Fall of Byzantium..., p. 259-261 (DuKAS, p. 431.22-433.21); Critobuli Imbriotae Historiae, p. 167.16-168.14; ÂşıK PAşAZADE, Osmanoğullarinın Tarihi, ed. K. Yavuz, M.A. Yekta SARaç, İstanbul 2003 (cetera: Âşı PAşAzAde), p. 512-514; Hoca Sadeddin Efendi, Tâcü't-tevârih, vol. III, ed. İ. ParmaksizoĞLu, Ankara 1979 (cetera: Hoca Sadeddin), p. 59-68; Müneccimbaşı Ahmed b. Lütfullah, Camiü'd-Düvel. Osmanlı Tarihi (12991481), ed. A. AĞIrakçA, İstanbul 1995 (cetera: Müneccimbaşı), p. 263-265; Kitâb-ı Cihan-nümâ. Neşrî Tarihi, vol. II, ed. F.R. Unat, M.A. Koymen, Ankara 1957, p. 755-759 (cetera: NeşRî). See also the available Bulgarian translation: Мехмед Нешри, Огледало на света. История на османския двор, ed. et trans. М. КАлицин, София 1984 (cetera: Мехмед Нешри), p. 290-291. Chalkokondyles' text is particularly detailed in the descriptions of the causes, developments and consequences of the Wallachian campaign. The chronicle did indeed tell of many abducted slaves and other loot, but according to the information also there is no doubt about the atmosphere of fear, panic and the high number of casualties in the Sultan's camp. Which actually explains the slaughter of all Wallachian warriors who fell into Ottoman captivity. Cf.: LAonikos Chalkoкondyles, p. 366-399.

${ }^{32}$ Without entering into specific details, it is enough only to recall that the Albanian warriors caught in captivity, as well as the men of the age fit to carry arms, were executed by the Ottoman army on the spot at every stop for camping. Cf.: Kritovoulos, p. 210-215, 218-219, 221-222; Tursun Beg, p. 55-56; Âşı Paşazade, p. 521-522; Hoca Sadeddìn, p. 91-94; Neşrî, p. 777, 779.

${ }^{33}$ Laonikos Chalkokondyles, p. 431. 
difficult to siege, the defenders destroyed the bridge over the river Sana. However, the Ottomans demonstrated persistence and reached the fortress. After the initial clashes, Mahmud Pasha began negotiations with King Stjepan Tomašević and persuaded him to surrender, assuring him that he and his men would not be harmed. Chalkokondyles accounts another division into three parts: one part of the city's inhabitants was left there; the second share was distributed among the Grand Vizier and his leading men; and the third was sent to Sultan Mehmed II ${ }^{34}$.

At first glance, the Ottomans were less brutal compared to their actions during the conquest of Morea or given the atrocities in the Wallachian campaign and in suppressing the Albanian resistance. The seemingly less cruel and ruthless subjugation of Lesbos and Bosnia demonstrates that the Ottoman position towards their captives (soldiers and civilians alike) was not arbitrary or aimless. With regard to the more merciful attitude as in the case of Mytilene, apart from the weak resistance and the rapid surrender, it is likely that other factors played their role. Between 1402 and 1462, the Gattilusio family promoted quite moderate and, - with necessary precaution - at times, even pro-Ottoman politics. They were dodging confrontation, tending to compromise and even cooperate, interested in the economic and political benefits they derived in the first and second quarter of the $15^{\text {th }}$ century. Undoubtedly, the Ottoman court also took into account the benefits that the cooperation with the Genoese in the eastern Mediterranean had to offer. In this connection, it is hardly a coincidence that in the former possession of Gattilusio - Phocaea - after its conquest by Sultan Mehmed II, Genoese with key skills and contacts retained their positions under the new masters ${ }^{35}$.

\footnotetext{
${ }^{34}$ Laonikos Chalkokondyles, p. 430-437. The promises however were not followed, and while Constantine Mikhailovich was attempting to attribute the guilt to the Grand Vizier, recounting the false oath, most of the sources indicate that the initiative for the perfidy comes from the Sultan himself. According to the notifications, Mehmed II was deeply angry at his talented commander and first Vizier and even consulted on the extent to which the rejection of the agreements between Mahmud Pasha and King Stjepan Tomašević and the execution of the latter could be justified according to the Islamic Law. Cf.: Konstantin Minailović, p. 137-141; Laonikos Chalkokondyles, p. 440-445; Tursun Beg, p. 50-51; Âşı Paşazade, p. 516-519; Müneccimbaşı, p. 266-268; Hoca Sadeddin, p. 70-74; G. Guillet de Saint-George, Histoire du regne de Mahomet II. Empereur des Turcs, vol. II, Paris 1690, p. 19-20; NeşRî,, p. 761-767 (cf.: Мехмед Hempu, p. 293-295). See also the comments and the enclosed bibliography: T. Stavrides, The Sultan of Vezirs. The Life and Times of the Ottoman Grand Vezir Mahmud Pasha Angelovic (1453-1474), Leiden-Boston-Köln 2001 [= OEH, 24], p. 147-149.

${ }^{35}$ Cf. K. Fleet, Turks, Mamluks, and Latin Merchants. Commerce, Conflict, and Cooperation in the Eastern Mediterranean, [in:] Byzantines, Latins, and Turks..., p. 327-344; C. WRIGHT, The Gattilusio Lordships..., p. 319-344, 407-411.
} 


\section{Beyond the phrase: Something more about the scope of the similarity}

Comparing the two rather distant chronological events, it should be stressed that in spite of the overwhelming similarity of the descriptions, concerning the division of the spoils of war, several significant differences are imposed. While the notice of the capture of the Longos fortress is found only in John Skylitzes, who wrote at a distance of several decades, the conquest of Lesbos is reflected by more than half a dozen authors. Additionally, the information can be found in texts composed by immediate participants and contemporaries as well as in the works of later chroniclers, regardless of their diverse origin, religion and public positions ${ }^{36}$.

In addition to the apparent imbalance in the volume of references and the number of authors in whose works they are found, it should be reported here that the question is about two rather different settlements. Longos' designation as a $\varphi$ poúpiov gives reasons to assume that it was one of the (probably not very large) fortifications near Kastoria, ensuring the protection of roads to the important provincial center ${ }^{37}$. As for Mytilene, the situation is quite different. The city is the most significant economic, administrative and spiritual center of the great Aegean island of Lesbos. It is located in the southeast part of the island, in a convenient mooring bay Gera. Until the fall of Mytilene under the Ottoman rule, the city had a history of two and a half millennia, intertwined with the fate of many significant personalities from Antiquity and the Middle Ages ${ }^{38}$. A lack of similarity is noticed

${ }^{36}$ Skylitzes, p. 355.17-26. See the available variety of records left by different Orthodox, Western and Ottoman (Muslim) authors: Kritovoulos, p. 180-184 (cf.: Critobuli Imbriotae Historiae, p. 168.20-172.30); Laonikos Chalkokondyles, p. 406-415; Dukas, p. 433.22-437.11 (cf.: Decline and Fall of Byzantium..., p. 261, 322-323, n. 325); Георгије Сфранцес, p. 193; Tursun Beg, p. 49-50; Neşrî, p. 759, 761; Hoca Sadeddin, p. 68-69; Müneccimbaşı, p. 265-266; ÂşıK Paşazade,

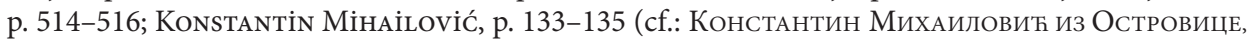
Јаничарове упомене или турска хроника, ed. et trans. Ђ. ЖивАиновит, Београд 1986, p. 138); Leonardi Chiensis de Lesbo a Turcis capta epistola Pio papae II missa, [in:] Chroniques Gréco-Romanes inédites ou peu connues, ed. C. Hopf, Berlin 1873, p. 359-366; G. Guillet DE SAINT-George, Histoire..., vol. I, Paris 1690, p. 486-496. During the preparation of the article inaccessible remained Ibn Kemal, Tevarih-i Al-i Osman, ed. et trans. Ş. Turan, Ankara 1957; Rûhî Târîhi, ed. H.E. Cengiz, Y. YÜCEL, Ankara 1992, as well as Enveri's Düstûrnâme and also the work on the history of the Ottoman Empire (Historia incrementorum atque decrementorum Aulae Othomanicae) written by Dimitrie Cantemir - YH, VK.

${ }^{37}$ Г.Н. Николов, Централизбм и регионализбм..., p. 176, 188.

${ }^{38}$ Among the most famous are the poets Sappho and Alcaeus, the philosophers Aristotle (settled briefly on the island from 337 to $335 \mathrm{BC}$ ) and Theophrastus, the notorious Roman commander and statesman Gaius Julius Caesar, Luke the Evangelist and Apostle Paul, the erudite Zacharias Rhetor and three brothers - saints and ascetics from the age of Iconoclasm - George, Simeon Stylites and David the Monk. The island and, in particular, its main town did once serve as a place for exile of political opponents and conspirators. On that list is the Emperor Constantine IX Monomachos (1042-1055) before his ascension to the throne. (Among the most prominent persons who have been exiled on Lesbos are the Empress Irene (797-802) as well as members of the Phokas family). 
not only with regard to the type of settlements, but also in connection with their future fate. It seems that Longos underwent serious damage and never recovered - especially in view of the fact that, at this stage, other information is not known, and even the very location of the fortress is subject to clarification. On the other hand, the economic profile and the significance of Mytilene as the most important city in the island of Lesbos are preserved for the subsequent centuries. Not only Kritoboulos' History of Mehmed the Conqueror but also a number of other sources leave no doubt that besides those who were the subject of deportation to the Bosphorus, a large group of islanders left on the spot ${ }^{39}$. Tursun, a participant in the events, writes that those townspeople and peasants who remained were undisturbed in their places and became subject to cizye [jizyah] and state taxation. Meanwhile... sancak beg, kādīis, garrison commanders, subaşis and sipāhis were appointed, and churches [most probably not all - $\mathrm{YH}, \mathrm{VK}$ ] were converted into mosques ${ }^{40}$.

Assuming that in the shares of the loot distributed between the Imperial warriors and the Russian detachment there were captives too, then in this particular regard a similarity between the conquest of Longos and the subjugation of Mytilene can be found. However, for the sake of objectivity, it should be emphasized that, despite the similarity concerning the distribution of the captives, there is one more significant distinction. Kritoboulos (not only he) clearly mentioned another (fourth) group of captives: Western mercenaries (Italians and Catalans), who fought on the side of the last Archon of Lesbos. Judging by the notifications offered, they were executed to the last person. Moreover, this merciless attitude was not an exception in the acts of the Ottomans from the mid-1450s-1460s and could be found even in cases in which Venetians, Catalans, Hungarians, or Genoese had previously shown mercy to captured Ottoman soldiers.

The feeling of difference grows additionally in the recognition of the peculiarities of military hostilities in the conquest of the two fortresses. From a religious point of view, the war between Byzantium and Bulgaria is an internal conflict within the Orthodox world, while the subjugation of Lesbos by the Ottomans in 1462 could be placed in the broader context of the conflict between the Islamic world and Christianity. Concerning the specific military-technical, tactical and strategic features, in general, it can be noted that this is done in terms of the decisive

\footnotetext{
${ }^{39}$ Cf. above n. 36. The late Byzantine chronicler of Imbros devoted a special place in his work on the description of the efforts made by the Ottoman ruler for reviving and restoring the city. His policy of the displacement of prisoners, not only in Istanbul, is well known and evidenced in other sources as well. For example, by recounting the end of the campaigns against Serbian Despotate in 1454 and 1455, Doukas notes that at the withdrawal of the Ottoman forces in 1454: Mehmed returned to Adrianople with the booty by way of Sofia. There he awarded one half to his officials and to the troops who had labored with him. After claiming half of the captives for himself, he sent them to populate the villages outside Constantinople. His allotted portion was four thousand men and women. - Decline and Fall of Byzantium..., p. 243.

${ }^{40}$ Tursun Beg, p. 49-50.
} 
superiority of the besiegers. In this regard, however, it is necessary to note that while Longos was taken at a very final stage in the course of the almost half-century Bulgarian-Byzantine struggles, the subjugation of Mytilene is only an episode of the even more prolonged actions of the Ottomans to conquer the islands of the Aegean and the liquidation of the presence of Western powers in the Eastern Mediterranean ${ }^{41}$.

\section{Conclusion}

In conclusion, it should be noted that the attempt to compare the two distant events is devoid of the ambition to propose a complete and detailed study of the fate of the prisoners, both in the epoch of the Byzantine military might in the early $11^{\text {th }}$ century and in the course of the Ottoman expansion in the third quarter of the $15^{\text {th }}$ century. In this regard, when attention is being paid to what is happening with the division of spoils of war as well as the fate of captives who have fallen into enemy hands, it seems as if it is most reasonable not to approach this one-sidedly. Many features, including religious and ethnic differences, must inevitably be taken into consideration as well as the duration of the conflict, the general moods among the regular military staff, the strategic and tactical endeavors of the army command, the logistical challenges of the guarding, feeding and transportation of the captives and - last but not least - the various benefits that can be derived from them.

As for the comparison attempt, in fact, despite the similarity of the descriptions pointed out at the beginning, it can be said that apart from the phrase used by John Skylitzes and Kritoboulos from Imbros, there are many very significant differences. In a more general context, the decisions implemented by the Emperor Basil II, and Sultan Mehmed II, regardless of whether fully compliant with statutory or traditional principles (or not), are reasoned by their policy of conquest, increased military costs and their willingness to motivate the participants in the marches with additional incentives and sometimes emphasized generosity at the expense of the spoils of war (in the broadest sense). The latter does not mean that in Byzantium during the last years of the reign of Emperor Basil II and in the Ottoman Empire after the conquest of Constantinople, the central authority passed lightly or deprived itself of the positives, which the deportations and the integration of prisoners provided in economic and demographic terms.

\footnotetext{
${ }^{41}$ Even before two full years had elapsed in the summer of 1464, in the face of the war with Venice, the island of Lesbos was not far from being lost by the Ottomans. - К. Имьър, Османската империя..., p. 267-268; T. STAVrides, The Sultan of Vezirs..., p. 155-157. Kritoboulos wrote that the Venetian Navy had seized most of the island but refrained itself from devastation. The fortress of Mytilene resisted. One well-equipped and trained Ottoman unit of 400 janissaries was located there. The resistance proved to be sufficiently successful and continuous, so that the Vizier Mahmud Pasha could arrive on time (Critobuli Imbriotae Historiae, p. 190.16-192.19; KRITOvoulos, p. 204-206).
} 


\section{Bibliography}

\section{Primary Sources}

Âşı Paşazade, Osmanoğullarinnn Tarihi, ed. K. Yavuz, M.A. Yekta Saraç, İstanbul 2003.

Basilikorum libri LX, Ser. A, vol. VIII, Lib. LX, ed. H.J. Scheltema, D. Holwerda, N. VAn Der Wal, Groningen 1988.

Critobuli Imbriotae Historiae, ed. D.R. ReInsch, Berolini-Novi Eboraci 1983 [= Corpus fontium historiae byzantinae. Series Berolinensis, 22].

Doukas, Decline and Fall of Byzantium to the Ottoman Turks, trans. H. Magoulias, Detroit 1975.

Dukas, Historia Turcobyzantina, ed. V. Grecu, Bucharest 1958.

Ecloga Leonis et Constantini, Epanagoge Basilii Leonis et Alexandri, ed. K.E. ZaCHARIAE von LiNGENTHAL, Lipsiae 1852.

Ekloga, Vizantijskij zakonodatel'ny svod VIII veka, ed. et trans. E.È. LıPšıc, Moskva 1965.

Georgije Sfrances, Hronika, ed. et trans. M. Stanković, Beograd 2011.

The History of Leo the Deacon. Byzantine Military Expansion in the Tenth Century, ed. et trans. A.-M. Talbot, D.F. Sullivan, Washington D.C. 2005 [= Dumbarton Oaks Studies, 41].

Hoca Sadeddin Efendi, Tâcü't-tevârih, vol. III, ed. İ. ParmaksizoĞLu, Ankara 1979.

Ioannis Scylitzae Synopsis Historiarum, ed. I. Thurn, Berolini-Novi Eboraci 1973 [= Corpus fontium historiae byzantinae, 5].

John Skylitzes, A Synopsis of Byzantine History, 811-1057, trans. J. Wortley, Cambridge 2010, https://doi.org/10.1017/CBO9780511779657

Kitâb-ı Cihan-nümâ. Neşrî Tarihi, vol. II, ed. F.R. Unat, M.A. Koymen, Ankara 1957.

Konstantin Mihailović, Memoirs of a Janissary, ed. et trans. B. Stolz, S. SouceK, Ann Arbor 1975 [= Michigan Slavic Translations, 3].

Konstantin Mihailovič iz Ostrovice, Janičarove upomene ili turska hronika, ed. et trans. Đ. ŽIIVANOvić, Beograd 1986.

Kritovoulos, History of Mehmed the Conqueror, trans. C.T. Riggs, Westport Conn. 1970.

Laonikos Chalkokondyles, The Histories, trans. A. Kaldellis, Cambridge Mass.-London 2014.

Leonardi Chiensis de Lesbo a Turcis capta epistola Pio papae II missa, [in:] Chroniques Gréco-Romanes inédites ou peu connues, ed. C. Hopf, Berlin 1873, p. 359-366.

Leonis VI Tactica, ed. et trans. G. DenNIs, Washington D.C. 2010 [= Corpus fontium historiae byzantinae, 49].

Mehmed NeŠri, Ogledalo na sveta. Istorija na osmanskija dvor, ed. et trans. M. KAliCIn, Sofija 1984.

Müneccimbaşı Ahmed b. Lütfullah, Camiü'd-Düvel. Osmanl Tarihi (1299-1481), ed. A. AĞIRAKÇA, İstanbul 1995.

O Procheiros nomos. Imperatorum Basilii, Constantini et Leonis Prochiron, ed. K.E. ZACHARIAE von Lingenthal, Heidelbergae 1837.

Pamjatniki literatury Drevnej Rusi. Načalo russkoj literatury. XI - načalo XII veka, ed. D.S. LICHAČEv, L.A. DMitriev, Moskva 1978.

Povest' vremennych let (po Lavrent'evskomu spisku 1377 goda), trans. D.S. LichačEv, O.V. Tvorogov, Sankt-Peterburg 2012. 
A Tenth-century Byzantine Military Manual. The Sylloge Tacticorum, trans. G. Chatzelis, J. Harris, London 2017 [= Birmingham Byzantine and Ottoman Studies, 22].

Tursun Beg, The History of Mehmed the Conqueror, ed. et trans. H. Inalcik, R. Murphey, Minneapolis-Chicago 1978.

\section{Secondary Literature}

Balard M., The Genoese in the Aegean (1204-1566), "Mediterranean Historical Review" 4, 1989, p. 158-174, https://doi.org/10.1080/09518968908569565

Bertosa B., The Treatment of Prisoners of War and Non-Combatants in Quran, "Canadian Military Journal" 8.1, 2007, p. 19-26.

BožIlov I., GJuzelev V., Istorija na Bălgarija v 3 toma, vol. I, Istorija na srednovekovna Bălgarija VII-XIV vek, Sofija 1999.

CodoñER J.S., Dates or Narrative? Looking for Structures in Middle Byzantine Historiography (9 $9^{\text {th }}$ to $11^{\text {th }}$ Century), [in:] Byzanz und das Abendland IV. Studia Byzantina-Occidentalia, ed. E. JuHÁsz, Budapest 2016, p. 227-255.

Croke B., Uncovering Byzantium's Historiographical Audience, [in:] History as Literature in Byzantium. Papers from the Fortieth Spring Symposium of Byzantine Studies, University of Birmingham, April 2007, ed. R. MACrides, Farnham 2010 [= Society for the Promotion of Byzantine Studies Publications, 15], p. 25-53.

Dain A., Le Partage du butin de guerre d'après les traités juridiques et militaires, [in:] Actes du VI Congrès international d'études byzantines, vol. I, Paris 1950, p. 347-354.

Drevnegrečesko-russkij slovar', vol. II, $M-\Omega$, ed. I.CH. DvoreCKIJ, Moskva 1958.

Edbury P., Christians and Muslims in the Eastern Mediterranean, [in:] The New Cambridge Medieval History, vol. VI, ed. M. Jones, Cambridge 2000, p. 864-884, https://doi.org/10.1017/ CHOL9780521362900.037

FILIPČUк A.M., Vizantijskie podchody XI veka k probleme plennych: osleplenie i ubijstvo, “Диалог со временем" / "Dialog so vremenem" 55, 2016, p. 330-340.

FleEt K., Ottoman Expansion in the Mediterranean, [in:] The Cambridge History of Turkey, vol. II, The Ottoman Empire as a World Power, 1453-1603, ed. S. FARUQHI, K. FleEt, Cambridge 2012, p. 141-172, https://doi.org/10.1017/CHO9781139049047.009

FleEt K., Turks, Mamluks, and Latin Merchants. Commerce, Conflict, and Cooperation in the Eastern Mediterranean, [in:] Byzantines, Latins, and Turks in the Eastern Mediterranean World after 1150, ed. J. Harris, C. Holmes, E. Russell, Oxford 2012, p. 327-344.

Fodor P., Ottoman Warfare, 1300-1453, [in:] The Cambridge History of Turkey, vol. II, Byzantium to Turkey, ed. K. FLEET, Cambridge 2009, p. 192-226, https://doi.org/10.1017/CHOL978052 1620932.007

Franklin S., Shepard J., The Emergence of Rus, 750-1200, London-New York 1996.

Guillet de SAint-George G., Histoire du regne de Mahomet II. Empereur des Turcs, vol. I-II, Paris 1690.

Haldon J., Warfare, State and Society in the Byzantine World, 565-1204, London 1999.

Heywood C., The Frontier in Ottoman History: Old Ideas and New Myths, [in:] Frontiers in Question. Eurasian Borderlands, 700-1700, ed. D. Power, N. Standen, London 1999, p. 228-249, https://doi.org/10.1007/978-1-349-27439-0_10 
Holmes C., Basil II and the Governance of Empire (976-1025), Oxford 2005, https://doi.org/10.1093/ acprof:oso/9780199279685.001.0001

Holmes C., Basil II the Bulgar-slayer and the Blinding of 15,000 Bulgarians in 1014: Mutilation and Prisoners of War in the Middle Ages, [in:] How Fighting Ends. A History of Surrender, ed. H. Afflerbach, H. Strachan, Oxford 2012, p. 85-95, https://doi.org/10.1093/acprof:oso/ 9780199693627.003.0007

Holmes C., The Rhetorical Structures of John Skylitzes' Synopsis Historion, [in:] Rhetoric in Byzantium. Papers from the Thirty-fifth Spring Symposium of Byzantine Studies, Exeter College, University of Oxford, March 2001, ed. E. JefFreys, Aldershot 2003, p. 187-199, https://doi.org/10.4324/ 9781315088686-14

Howard-Johnston J., Historical Writing in Byzantium, Heidelberg 2014.

Hristov Y., A Glimpse at the Fate of the Byzantine Prisoners of War in Bulgaria during the Period from 976 to 1018, "Епохи" / "Epohi" 27.2, 2019, p. 406-414.

Hristov Y., Prisoners of War in Early Medieval Bulgaria (Preliminary Remarks), "Studia Ceranea. Journal of the Waldemar Ceran Research Center for the History and Culture of the Mediterranean Area and South-Eastern Europe" 5, 2015, p. 73-105, https://doi.org/10.18778/2084140X.05.03

IMBĂR K., Osmanskata imperija 1300-1481, Sofija 2000.

İNalcik H., Ottoman Methods of Conquest, [in:] H. İNalcik, The Ottoman Empire. Conquest, Organization and Economy. Collected Studies, p. 1, London 1978, p. 104-129.

INALDŽĂK H., Osmanskata imperija. Klasičeskijat period 1300-1600, Sofija 2002.

Jennings R., Some Thoughts on the Gazi-Thesis, "Wiener Zeitschrift für die Kunde des Morgenlandes" 76, 1986, p. 151-161.

Kafadar C., Between Two Worlds. The Construction of the Ottoman State, Berkley 1995.

Kaldellis A., The Manufacture of History in the Later Tenth and Eleventh Centuries: Rhetorical Templates and Narrative Ontologies, [in:] Proceedings of the 23 $3^{\text {rd }}$ International Congress of Byzantine Studies. Belgrade 22-27 August 2016. Plenary Papers. Belgrade 2016, ed. S. Marjanović-DušAnić, Belgrade 2016, p. 293-306.

Kaldy-Nagy G., The Holy War (jihad) in the First Centuries of the Ottoman Empire, "Harvard Ukrainian Studies" 3-4, 1979-1980, p. 467-473.

Kastritsis D., Conquest and Political Legitimation in the Early Ottoman Empire, [in:] Byzantines, Latins, and Turks in the Eastern Mediterranean World after 1150, ed. J. HARRIS, C. Holmes, E. RusSELL, Oxford 2012, p. 221-263, https://doi.org/10.1093/acprof:osobl/9780199641888.003.0008

KHADduri M., War and Peace in the Law of Islam, Baltimore 1955.

Koder J., Stouraitis I., Byzantine Approaches to Warfare (6 $6^{\text {th }}-12^{\text {th }}$ Centuries). An Introduction, [in:] Byzantine War Ideology between Roman Imperial Concept and Christian Religion, ed. J. Koder, I. Stouraitis, Vienna 2012, p. 9-15.

Kolia-Dermitzaki A., Some Remarks on the Fate of Prisoners of War in Byzantium ( $9^{\text {th }}-10^{\text {th }}$ Centuries), [in:] Atti del Congresso interdisciplinare di studi storici, ed. G. Gipollone, Città del Vaticano 2000 [= Collectanea Archivi Vaticani, 46], p. 583-620.

Kondyli F., Lords at the End of the Empire: Negotiating Power in the Late Byzantine Frontiers (Fourteenth-Fifteenth Centuries), "The Annual of the British School at Athens" 112, 2017, p. 309-339, https://doi.org/10.1017/S0068245417000077

KuČma V.V., Voennaja organizacija Vizantijskoj imperii, Sankt-Peterburg 2001. 
KYrIAKIDIs S., The Division of Booty in Late Byzantium (1204-1453), "Jahrbuch der Österreichischen Byzantinistik” 59, 2009, p. 163-175, https://doi.org/10.1553/joeb59s163

Laiou A., On Just War in Byzantium, [in:] To Hellenikon. Studies in Honor of Speros Vryonis Jr., vol. I, ed. S. Reinert, J. Langdon, A. Allen, New Rochelle-New York 1993, p. 153-174 (= A. Laiou, On Just War in Byzantium, [in:] Byzantine Warfare, p. I.2, ed. J. Haldon, Aldershot 2007, p. 153-174).

Liddell H.G., Scott R., Jones H.S., McKenzie R., A Greek-English Lexicon, ${ }^{9}$ Oxford 1996.

Lyкаке̄ M., Oi aichmalōtoi polemou stē Byzantivē Autokratoria (6 $6^{o s}-11^{o s}$ ai). Ekklēsia, Kratos, diplōmatia kai koivōnikē diastasē, Ėthniko kai Kapodistriako Panepistēmio Athēnōv, Athēna 2016 (unpublished $\mathrm{PhD}$ dissertation).

Magdalino P., Byzantine Historical Writing, 900-1400, [in:] The Oxford History of Historical Writing, vol. II, 400-1400, ed. S. Foот, C.F. Robinson, Oxford 2012, p. 218-237.

McGeer E., Sowing the Dragon's Teeth. Byzantine Warfare in the Tenth Century, Washington D.C. 1995 [= Dumbarton Oaks Studies, 33], p. 171-362.

Mullet M., Aristocracy and Patronage in the Literary Circles of Comnenian Constantinople, [in:] The Byzantine Aristocracy, IX to XIII Centuries, ed. M. Angold, Oxford 1984, p. 173-187.

Munir M., Debates on the Rights of Prisoners of War in Islamic Law, "Islamic Studies" 49.4, 2010, p. 463-492, https://doi.org/10.2139/ssrn.1802006

Neville L., Guide to Byzantine Historical Writing, Cambridge 2018, https://doi.org/10.1017/ 9781139626880

Nikolov G.N., The Bulgarian Aristocracy in the War against the Byzantine Empire (971-1019), "Byzantina et Slavica Cracoviensia" 3, 2001, p. 141-158.

Nikolov G.N., Centralizăm i regionalizăm v rannosrednovekovna Bălgarija (kraja na VII - načaloto na XI v.), Sofija 2005.

Nilsson I., To Narrate the Events of the Past: On Byzantine Historians, and Historians on Byzantium, [in:] Byzantine Narrative. Papers in Honour of Roger Scot, ed. J. Burke et al., Melbourne 2006 [= Byzantina Australiensia, 16], p. 47-58, https://doi.org/10.1163/9789004344877_004

Patoura S., Oi aichmalōtoi ōs paragontes epikoinōnias kai plērophorēsēs ( $4^{o s}-10^{o s}$ ai.), Athēna 1994.

PAvlov P., Boris i Roman - tragedijata na carskija rod v kraja na X vek, [in:] P. PAVlov, Zabraveni i nerazbrani. Săbitija i ličnosti ot Bălgarskoto srednovekovie, Sofija 2012, p. 53-83.

Pirivatrić S., Samuilova država. Obim i karakter, Beograd 1997.

Prinzing G., On Slaves and Slavery, [in:] The Byzantine World, ed. P. Stephenson, London-New York 2010, p. 92-102.

PrInZING G., Slavery in Byzantium from 566 until 1453, [in:] Proceedings of the $23^{\text {rd }}$ International Congress of Byzantine Studies. Belgrade, 22-27 August 2016. Round Tables, ed. B. Krsmanović, L. Milanović, Belgrade 2016, p. 176-181.

Ramadān A., The Treatment of Arab Prisoners of War in Byzantium, $9^{\text {th }}-10^{\text {th }}$ Centuries, "Annales Islamologiques" 43, 2009, p. 155-194.

Rotman Y., Byzantine Slavery and the Mediterranean World, trans. J.M. TodD, Cambridge Mass.London 2009.

Roueché C., Byzantine Writers and Readers: Storytelling in the Eleventh Century, [in:] The Greek Novel, A.D. 1-1985, ed. R. Beaton, London 1987, p. 123-133. 
Salaymen L., Early Islamic Legal-Historical Precedents: Prisoners of War, "Law and History Review" 26.3, 2008, p. 521-544, https://doi.org/10.1017/S0738248000002558

Schreiner P., Die vermeintliche Blendung. Zu den Ereignissen von Kleidion im Jahr 1014, [in:] Evropejskijat Jugoiztok prez vtorata polovina na X - načaloto na XI vek. Istorija i kultura, ed. V. GJUZELEV, G.N. NiKolov, Sofija 2015, p. 170-190.

Simeonova L., In the Depths of Tenth-Century Byzantine Ceremonial: the Treatment of Arab Prisoners of War at Imperial Banquets, "Byzantine and Modern Greek Studies" 22, 1998, p. 75-104, https://doi.org/10.1179/byz.1998.22.1.75

Simeonova L., Semiotika na uniženieto: Visokopostaveni čuždenci v imperskata stolica prez X vek, "Родина" / "Rodina" 4, 1996, p. 29-43.

SinclaIR K.J., War Writing in Middle Byzantine Historiography. Sources, Influences and Trends, Birmingham 2012 (unpublished Phd dissertation).

Starogrăcko-bălgarski rečnik, ed. M. Vojnov, D. DečEv, V. Georgiev, A. Milev, B. Gerov, M. Tonev, ${ }^{2}$ Sofija 1943.

Stavrides T., The Sultan of Vezirs. The Life and Times of the Ottoman Grand Vezir Mahmud Pasha Angelovic (1453-1474), Leiden-Boston-Köln 2001 [= The Ottoman Empire and its Heritage, 24].

Stephenson P., The Legend of Basil the Bulgar-Slayer, Cambridge 2003.

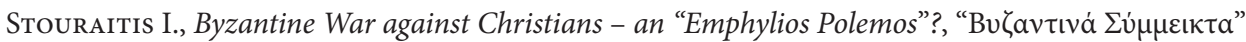
/ "Byzantina Symmeikta" 20, 2010, p. 85-110, https://doi.org/10.12681/byzsym.964

Stouraitis I., 'Just War' and 'Holy War' in the Middle Ages. Rethinking Theory through the Byzantine Case-Study, "Jahrbuch der Österreichischen Byzantinistik" 62, 2012, p. 227-264, https://doi. org/10.1553/joeb62s227

Tomov T., Bitkata pri Ključ prez 1014 g., [in:] Evropejskijat Jugoiztok prez vtorata polovina na X - načaloto na XI vek. Istorija i kultura, ed. V. GJuzelev, G.N. Nikolov, Sofija 2015, p. 142-169.

Toynbee A.J., Constantine Porphyrogenitus and his World, Oxford 1973.

Treadgold W., Byzantium, the Reluctant Warrior, [in:] Noble Ideals and Bloody Realities. Warfare in the Middle Ages, ed. N. Christie, M. Yazigi, Leiden-Boston 2006, p. 209-233.

Treadgold W., The Unwritten Rules for Writing Byzantine History, [in:] Proceedings of the $23^{\text {rd }}$ International Congress of Byzantine Studies. Belgrade 22-27 August 2016. Plenary Papers. Belgrade 2016, ed. S. MarJanović-Dušanić, Belgrade 2016, p. 277-292.

WhitTow M., The Making of Orthodox Byzantium, 600-1025, London 1996, https://doi.org/10.1007/ 978-1-349-24765-3

Wierzbiński S., Prospective Gain or Actual Cost? Arab Civilian and Military Captives in the Light of Byzantine Narrative Sources and Military Manuals from the $10^{\text {th }}$ Century, "Studia Ceranea. Journal of the Waldemar Ceran Research Center for the History and Culture of the Mediterranean Area and South-Eastern Europe" 8, 2018, p. 253-283, https://doi.org/10.18778/2084-140X.08.14

Wright C., Byzantine Authority and Latin Rule in the Gattilusio Lordships, [in:] Byzantines, Latins, and Turks in the Eastern Mediterranean World after 1150, ed. J. Harris, C. Holmes, E. Russell, Oxford 2012, p. 247-263, https://doi.org/10.1093/acprof:osobl/9780199641888.003.0009

Wright C., The Gattilusio Lordships and the Aegean World, 1355-1462, Leiden-Boston 2014 [= The Medieval Mediterranean, 100], https://doi.org/10.1163/9789004264816

ZlatARsKi V., Istorija na bălgarskata dăržava prez srednite vekove, vol. I, p. 2, Ot slavjanizacijata na dăržavata do padaneto na Părvoto carstvo (852-1018), Sofija 1927. 


\begin{abstract}
One can say without hesitation that during the highly dynamic medieval epoch rivalries and military clashes were of paramount importance in the struggles for dominance over the Balkan Peninsula. During the entire period, war-time activities included the capturing of those who had the misfortune to fall into the hands of the enemy. Various groups of soldiers and civilians alike have repeatedly tested the bitterness of captivity. Attempts to trace the fate of war-captives are, for understandable reasons, directly dependent on the data in the written records. The comparison of the various historical accounts is rather typical, even if the records deal with events that are different in time, place and participants. The present paper also compares two descriptions. This study encompasses two well-known historical accounts: the first one is from the chronicle (Synopsis historiarum) of John Skylitzes, while the second one is excerpted from Kritoboulos' History of Mehmed the Conqueror. Despite all distinctions, there are some particular similarities. Both fragments concern the division of the spoils of war and the fate of the captured population and provide additional knowledge of the practices relating to prisoners of war in the Balkan medieval past.
\end{abstract}

Keywords: Byzantino-Bulgarian conflict, Ottoman conquest, prisoners of war, captivity, enslavement, deportation, execution

Yanko Hristov

South-West University "Neofit Rilski”

Faculty of Law and History

Department of History

66 Ivan Mihaylov Str.

2700 Blagoevgrad, Bulgaria

hristiqnko@gmail.com

Valentin Kitanov

South-West University "Neofit Rilski"

Faculty of Law and History

Department of History

66 Ivan Mihaylov Str.

2700 Blagoevgrad, Bulgaria

kitvalmil@swu.bg 